\title{
Feeding habits, Overweight, Obesity and Hypertension and Associated Factors among Polytechnic Students in Ekiti State, Southwest Nigeria
}

\author{
I.O. Dada* and I.A. Igbe \\ Department of Human Nutrition and Dietetics, College of Medicine and Health Sciences, Afe Babalola University, \\ Ado-Ekiti, Nigeria \\ *iodada@abuad.edu.ng (Corresponding Author)
}

\section{ARTICLE INFORMATION}

Received: September 06, 2019

Revised: November 16, 2020

Accepted: December 21, 2020

Published Online: January 29, 2021

Keywords:

Overweight, Obesity, Blood pressure,

Feeding pattern, Higher institution students

\begin{abstract}
Overweight and obesity is a risk factor to chronic non-communicable diseases. This study assessed level of overweight/obesity and blood pressure among students of a higher institution in Southwest Nigeria. This cross-section study involved 300 students of a public higher institution in AdoEkiti, Southwest, Nigeria. A validated self-administered questionnaire was used to collect data on personal characteristics, feeding pattern and lifestyle of the students. Body Mass Index (BMI) was categorized into normal weight $(\mathrm{BMI}<25)$ and overweight/obesity $(\mathrm{BMI} \geq 25)$. Waist circumference and waist-hip-ratio (WHR) were classified as normal and at risk. Hypertension was defined as systolic blood pressure (SBP) $\geq 140 \mathrm{mmHg}$ and diastolic blood pressure (DBP) $\geq 90 \mathrm{mmHg}$. Chi square test was used to establish relationship between variables at $5 \%$ level of significance. The mean age of the students was 22.25 years and $62.8 \%$ were above 20years. Monthly allowance less than $\$ 30000.00$ was received by $64.4 \%$ of the students, $47.3 \%$ skipped breakfast meal, $96 \%$ consumed carbonated soft drinks and 37.1\% did not engaged in physical exercise. Prevalence of general obesity was $17.1 \%(\mathrm{BMI} \geq 25) ; 7 \%$ and $15.5 \%$ were at risk of abdominal and central obesity respectively. Students in systolic pre-hypertension and stage I hypertension were $33.3 \%$ and $3 \%$ respectively whereas $15.5 \%$ and $2.4 \%$ were in diastolic pre-hypertension and stage I hypertension respectively. Female gender, monthly allowance less than $\$ 30000.00$ and adolescent stage were associated with obesity. Older age, male gender and monthly allowance less than $\$ 30000.00$ were associated with BP. Nutrition education is recommended for this population group.
\end{abstract}

\& Alqubati, 2020; Arisa et al., 2020). A study on students of a Federal Polytechnic in Nigeria revealed that more than half of the students consumed alcohol (Agwo \& Adewunmi, 2020).

Studies had implicated overweight/obesity as one of the main risk factors that predispose individuals to various chronic non-communicable diseases such as hypertension, type 2 diabetes mellitus, gallstones, respiratory system problems, sleep apnoea, cardiovascular diseases, cancer (WHO, 2003; Agwu et al., 2017). Globally, there is a rising prevalence of overweight and obesity among this population group in both developing and developed countries. Studies in Africa revealed a prevalence of $13 \%$ and $5 \%$ in Ghana (Mogre et al., 2014), 39\% and 17\% in Egypt (Moussa et al., 2016) and, $24 \%$ and $2 \%$ in Cameroun (Niba et al., 2017) of overweight and obesity respectively. The prevalence of overweight/ obesity in Uganda and Botswana was 15\% (Kolawole et al., 2017) and 36\% (Tapera et al., 2017) respectively. In the 
Middle East, overweight and obesity prevalence of $28 \%$ and 16\% respectively was observed in Saudi Arabia (Issa, 2015). Asia statistics show a prevalence of $14 \%$ overweight/obesity in Malaysia (Gan et al., 2011; Kutty et al., 2015), 11\% and $2 \%$ overweight and obesity prevalence in China (Ren et al., 2015) and in Pakistan 13\% and 2\% overweight and obesity prevalence respectively (Irfan, 2018). Eastern Europe has a record of $37 \%$ overweight/obesity prevalence in Mexico (Sofia et al., 2015). The results of studies in South America showed an overweight prevalence of 35\% (Moretti et al., 2014) and 5\% obesity prevalence (Obesidade \& Obesidad, 2017) in Brazil.

Previous studies on students of higher institutions across Nigeria reveal high prevalence of overweight ranging from $4 \%$ to $40 \%$ and obesity was between $2.7 \%$ and 18\% (Oghagbon et al., 2009; Ayodele et al., 2009; Aliyu et al., 2014; Oladoyinbo \& Ekerette, 2015; Ukegbu et al., 2015; Attah et al., 2016; Agwu et al., 2017; Maduka et al., 2017; Okafor et al., 2018; Obasi et al., 2019). The highest prevalence of overweight was recorded in the Eastern part (Okafor et al., 2018) while the least was in the Northern part (Aliyu et al., 2014) of the country. The highest and lowest prevalence of obesity on the other hand was recorded in the Western Nigeria (Olusanya \& Omotayo, 2011; Olufemi \& Abiodun, 2013; Oladoyinbo \& Ekerette, 2015). Recent studies on university students still showed high prevalence of overweight and obesity. A 40\% prevalence of overweight/obesity was recorded among private university students in Southwest Nigeria (Kayode \& Alabi, 2020) and $31 \%$ obesity prevalence was found among students of public university in Northern Nigeria (Gwarzo et al., 2020).

Studies across Nigeria and other countries among students of tertiary institutions identified predisposing factors to overweight and obesity. These include: skipping meals and consumption of unhealthy snacks (Ukegbu et al., 2017). Other factors are intakes of fibre, gender, sedentary lifestyle, older age, alcohol consumption, higher pocket money, sleeping less than 8hours in a day, and being in marriage (Aliyu et al., 2014; Moretti et al., 2014; Mogre et al., 2014; Issa, 2015; Kutty, 2015; Sofia et al., 2015; Katuka et al., 2016; Kolawole et al., 2017; Obesidade \& Obesidad, 2017; Deng et al., 2017).

Recent findings of studies in Southwest region of Nigeria revealed that different level of physical activity and days of physical activity correlated with general and central obesity among university students (Sedodo et al., 2020; Arisa et al., 2020; Ikujenlola \& Adekoya, 2020). Lack of physical activity was found to contribute to obesity in $86 \%$ of private university students in the region (Okondu et al., 2020). In Yemen, more than half $(58 \%)$ of university students who did not involve in physical activity had overweight/obesity prevalence that was more than three times higher compared to other students (Alhaji \& Alqubati, 2020). Similarly, smokers were found to be more than two times overweight and obese compared with non-smokers.

Unhealthy feeding habit is a risk for non-communicable diseases (Abdulfatah, 2020). The study of Sedodo et al. (2020) showed that not less than $60 \%$ of polytechnic students in Abeokuta preferred fast foods to homemade meals. Two thirds of private university students in Ede, Osun State consumed snacks daily; fruits (18\%) and vegetables (25\%) were consumed by a small proportion of the students (Kayode \& Alabi, 2020). The authors observed that vegetable intakes lower general obesity. In another study in Osun State, about half of university students consumed fruits and vegetables less than three times in a week (Ikujenlola \& Adekoya, 2020). A study among university students in Lagos showed that $83 \%$ skipped meals and $75 \%$ skipped breakfast (Arisa et al., 2020). These authors found skipping of breakfast as a predictor of overweight and obesity. In a study among polytechnic students in Ogun State, $72 \%$ of the students skipped breakfast and replaced lunch with snacks (Alaba, 2018). Among Iranian university students, eating breakfast more than four days in a week lower the risk of overweight by $15 \%$ and obesity by $33 \%$ (Mansouri et al., 2018).

Hypertension is a metabolic factor that is associated with overweight and obesity. It has been observed to be higher in overweight and obese university students (Moretti et al., 2014; Issa, 2015; Moussa et al., 2016; Maduka et al., 2017; Ukegbu et al., 2017; Gyamfi, 2018). In Egypt and Ghana, more than $50 \%$ of university students were hypertensive (Moussa et al., 2016; Gyamfi et al., 2018). Studies in Nigeria among university students found hypertension to be higher in males than in females (Gwarzo et al., 2020; Ezeh \& Kadiri, 2020).

Most of the previous study on overweight and obesity were on university students. There is a dearth of information on polytechnic students on this nutritional issue. Hence, this study was designed to assess the prevalence of overweight and obesity and hypertension among polytechnic students in Ado-Ekiti, southwest, Nigeria. The study will add to the existing data on the nutritional status of this population group in Nigeria. It will equally provide valuable information for nutritionists and health personnel to understand the nutritional challenge of this group and help to plan adequate intervention strategy to address nutritional problems of the group.

\section{Materials and Methods}

\section{Study Design}

This study was a descriptive cross-sectional design involving 300 students of Federal Polytechnic, Ado-Ekiti. Federal 
Polytechnic Ado-Ekiti, Ekiti State, South West, Nigeria was established in 1977 and now has a student population of over 10,000 (full-time and part-time National Diploma and Higher National Diploma, Certificate and Professional programmes). The respondents were students of Federal Polytechnic, Ado-Ekiti. They were from the four faculties of the institution which are faculty of Business studies, faculty of Engineering, faculty of Environmental studies, Faculty of Sciences and Computer science. The students either leave on campus or off campus. Most students prepare their meals themselves or buy food from local food vendors.

\section{Sample Size Determination}

The sample size was calculated using Fisher's statistical formula. Taking a precision of 0.05 at $95 \%$ confidence interval $(\mathrm{Z})$, the minimum size $(\mathrm{N})$ calculate by single proportion formula based on $26.2 \%$ (Oghagbon et al., 2009) estimated prevalence of overweight was calculated thus,

$$
\mathrm{N}=\frac{\mathrm{Z}^{2} \mathrm{pq}}{\mathrm{D}^{2}}
$$

Where, $Z^{2}=$ Confidence level 95\%

$$
\begin{aligned}
& \mathrm{N}=\text { Minimum sample size } \\
& \mathrm{D}=\text { Desired precision }=0.05 \\
& \mathrm{p}=\text { Estimated prevalence of overweight and } \\
& \text { Obesity at } 26.2 \% \\
& \mathrm{q}=1-\mathrm{p}=0.738 \\
& \mathrm{~N}=\frac{1.96^{2} \times 0.262 \times 0.738}{0.05^{2}}
\end{aligned}
$$

The minimum number of students that was used for this study was 300 .

\section{Sampling Procedures}

Respondents were taken from all four faculties. There are 5 departments in Faculty of Business studies, 3 departments in faculty of Sciences and Computer science, 4 departments in Environmental sciences and 10 departments in Engineering. Seventy-five students were randomly selected from each faculty.

\section{Instrument for Data Collection}

A semi-structured interviewer-administered questionnaire was used to collect data; the questionnaire had different sections based on study objectives. A weighing scale was used to weigh the respondents. A measuring tape was used to measure the waist and hip circumferences.

\section{Data Collection}

Data collection took place in participants' classroom with a questionnaire to obtain information on their personal characteristics, feeding pattern, physical activity level and lifestyle.

\section{Measurement of Weight}

The weight of the respondents was measured using a bathroom scale (Model: H89 DK Blue, serial number 5099838000448). The bathroom scale was placed on a hard level surface. Calibration was done at regular interval of measurements to ensured quality control. Respondents were asked to remove their heavy garments and shoes and other items that may affect the weight. Reading was done to the nearest $0.5 \mathrm{Kg}$

\section{Measurement of Height}

The height of the respondents was measured using a calibrated standiometer consisting of a horizontal base with a vertical tape. Each respondent was asked to remove his/her shoes, heavy garments and hair ornaments before reading was taken to the nearest $0.1 \mathrm{~cm}$.

The Body Mass Index was calculated using the weight $(\mathrm{kg})$ and height $(\mathrm{m})$; this was categorized into normal weight $(\mathrm{BMI}<25)$ and overweight/obesity (BMI $\geq 25)$.

\section{Measurement of Waist Circumference}

Waist circumference was measured using a tape rule. The subject was asked to remove all heavy clothing around the waist (belts and other thick clothing) before the measurement was taken to ensure accuracy. The waist circumference was taken at the midpoint between the lower border of the rib cage and the iliac crest, the subject was asked to stand erect and the tape rule was wrapped round the waist from zero mark and the reading was taken to the nearest $0.1 \mathrm{~cm}$. The waist circumference was categorized into safe for male $(<94 \mathrm{~cm})$ and female $(<80 \mathrm{~cm})$ and at risk for male $(\geq 94 \mathrm{~cm})$ and female $(\geq 80 \mathrm{~cm})$.

\section{Measurement of Hip Circumference}

Hip circumference was measured using a tape rule. The respondents were asked to spread their arms and the tape was placed round the highest circumference of the gluteal region. Moving the tape to and fro until a highest value was read. Care was taken to prevent indenting the buttocks. The measurement was taken to the nearest $0.1 \mathrm{~cm}$. The hip circumference was divided by waist circumference to obtain waist-hip-ratio. The waist-hip-ratio was classified into safe for male $(\leq 0.95)$ and female $(\leq 0.80)$ and at risk for male $(>0.95)$ and female $(>0.80)$. 


\section{Blood Pressure Measurement}

An electronic blood pressure monitor (Andon, model KD-595) with serial number CE 0197, was used in the measurement of the blood pressure of the respondent. Each subject was made to seat quietly for at least five minutes before reading was taken. Both the SBP and DBP were recorded. The measurement was taken twice and the average was recorded. The measured blood pressure values were classified as normal, pre-hypertension, stage I or II hypertension. Hypertension was defined as systolic blood pressure $(\mathrm{SBP}) \geq 140 \mathrm{mmHg}$ and diastolic blood pressure $(\mathrm{DBP}) \geq 90 \mathrm{mmHg}$.

\section{Inclusion and Exclusion Criteria}

Students who were pregnant, on medication, pursuing certificate courses and professional courses and those that were physically challenged were not included in the study.

\section{Ethical Consideration}

Approval for the study was obtained from the Ethical Research Committee of Afe Babalola University, Ado-Ekiti, Nigeria. The consent of the respondents was taken verbally. They gave their approval to be assessed and measured. To ensure confidentiality, their names were not mentioned on the questionnaire.

\section{Data Analysis}

Data entry and analysis was done using Statistical Package for the Social Sciences (SPSS) software version 20.0. Data cleaning was done by running frequencies of all relevant variables to identify inadequate entries and missing values. Descriptive statistics was generated; categorical variables were presented using frequencies and percentages. Chisquare analysis was done to establish relationship between variables at $5 \%$ level of significance.

\section{Results and Discussion}

\section{Personal Characteristics of the Respondents}

The personal characteristics of the respondents are presented in Table 1. A total of 300 respondents were sampled with $56.7 \%$ males and $43.3 \%$ females. The mean age was $22.25 \pm 3.30$ and more than half $(62.8 \%)$ were above 20 years. Respondents were majorly (90.6\%) Yoruba and about half of the respondents' fathers (47.5\%) and mothers (48.1\%) had tertiary education. More (42.8\%) respondents collected a monthly allowance of less than 20,000 , and $30.1 \%$ collected above $\$ 40,000$.
Table 1: Personal characteristics of respondents

\begin{tabular}{|c|c|c|}
\hline Characteristics & $\mathbf{N}$ & $(\%)$ \\
\hline \multicolumn{3}{|l|}{ Age } \\
\hline $15-20$ & 107 & 37.2 \\
\hline 21 and above & 181 & 62.8 \\
\hline Total & 288 & \\
\hline Mean & $22.25 \pm 3.303$ & \\
\hline \multicolumn{3}{|l|}{ Ethnicity } \\
\hline Hausa & 1 & 0.3 \\
\hline Igbo & 8 & 2.7 \\
\hline Yoruba & 271 & 90.6 \\
\hline Others & 19 & 6.4 \\
\hline Total & 299 & \\
\hline \multicolumn{3}{|l|}{ Religion } \\
\hline Christianity & 266 & 89.3 \\
\hline Islam & 30 & 10.1 \\
\hline Others & 2 & 0.7 \\
\hline Total & 298 & \\
\hline \multicolumn{3}{|l|}{ Faculty } \\
\hline Business studies & 79 & 26.4 \\
\hline Engineering & 74 & 24.7 \\
\hline Computer science and sciences & 79 & 26.4 \\
\hline Environmental sciences & 67 & 22.4 \\
\hline Total & 299 & \\
\hline \multicolumn{3}{|l|}{ Level } \\
\hline OND 1 & 147 & 49.2 \\
\hline OND 2 & 26 & 8.7 \\
\hline HND 1 & 40 & 13.4 \\
\hline HND 2 & 86 & 28.8 \\
\hline Total & 299 & \\
\hline \multicolumn{3}{|l|}{ Educational level of mother } \\
\hline None & 15 & 5.1 \\
\hline Primary & 36 & 12.1 \\
\hline Secondary & 103 & 34.7 \\
\hline Tertiary & 143 & 48.1 \\
\hline Total & 297 & \\
\hline \multicolumn{3}{|l|}{ Educational level of father } \\
\hline None & 20 & 6.8 \\
\hline Primary & 36 & 12.2 \\
\hline Secondary & 99 & 33.6 \\
\hline Tertiary & 140 & 47.5 \\
\hline Total & 295 & \\
\hline \multicolumn{3}{|l|}{ Monthly allowance } \\
\hline Less than $\approx 20,000$ & 115 & 42.8 \\
\hline 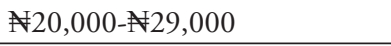 & 58 & 21.6 \\
\hline N30,000- $¥ 39,000$ & 15 & 5.6 \\
\hline Above 40,000 & 81 & 30.1 \\
\hline Total & 269 & \\
\hline
\end{tabular}




\section{Respondents' Feeding Pattern and Lifestyle}

The feeding pattern and lifestyle of the respondents are presented in Table 2 with $48.2 \%$ of the respondents eating three times daily and $43.4 \%$ eating less than three times daily; $74.9 \%$ skipped meals. Nearly half (47.3\%) of the respondents skipped breakfast and 59.5\% had their breakfast 7 days a week. Lifestyle of respondents revealed that alcohol was consumed by $24.1 \%$ of the respondents and $96.0 \%$ of them consumed carbonated soft drink with $19.6 \%$ consuming it daily. More than one third (37.1\%) of the students did not engage in physical exercise and a total of $12.7 \%$ engaged in physical exercise more than three days in the past one week.

\section{Weight Status and Blood Pressure of Respondents}

The mean BMI of the students was $22.35 \pm 3.36$ with $82.9 \%$ having BMI below 25 and $17.1 \%$ had BMI of 25 and above. Figure 1 shows that $82 \%$ of males and $66 \%$ of females had normal weight, The prevalence of overweight and obesity was higher among females ( $18 \%$ and $5 \%$ ) compared to males $(12 \%$ and $1 \%)$. The mean waist circumference was $73.84 \pm 7.08$. Figure 2 presents the waist circumference of the respondents. Only female (7.0\%) respondents were at risk. The mean waist-hip-ratio was $0.80 \pm 0.05$. Figure 3 presents the waist-hip-ratio of respondents. Only female (15.5\%) respondents were at risk. The mean systolic BP was $115.33 \pm 13.19$ and $63.3 \%$ of the students were normal, $33.3 \%$ were in pre-hypertension stage and $3.0 \%$ were in stage I hypertension. The mean diastolic BP was $72.88 \pm 0.05$ with $81.8 \%, 15.5 \%$ and 2.4 of the students in normal, pre-hypertension and stage I hypertension respectively. Figure 4 presents the blood pressure of the respondents. Majority $(67.2 \% \mathrm{~F}, 47.9 \% \mathrm{M})$ of the respondents were of normal blood pressure. Pre-hypertensive respondents were higher in male (46.7\%) than female (30.5\%). Respondents at stage I hypertension were higher in male (4.7\%) than female (1.6\%).

\section{Association of Anthropometry Indicators with Other Variables}

Table 3 shows the body mass index (BMI) according to personal characteristics of respondents. Among the respondents with $\mathrm{BMI} \geq 25,67.3 \%$ were above 20 years and more than half $(56.9 \%)$ were females. Overall, $69.7 \%$ of the students that received less than $\$ 30,000.00$ as monthly allowance were overweight or obese.

The waist circumference (Table 4) shows that more females $(100.0 \%)$ than males $(0.0 \%)$ were at risk of abdominal obesity. Overall, students that received monthly allowance of less than $\$ 30,000.00$ (77.8\%) were at risk
Table 2: Feeding pattern and lifestyle of respondents

\begin{tabular}{|c|c|c|}
\hline Meal & n & $\%$ \\
\hline \multicolumn{3}{|c|}{ Number of meals per day } \\
\hline$<3$ & 130 & 43.4 \\
\hline 3 & 144 & 48.2 \\
\hline$>3$ & 25 & 8.4 \\
\hline Total & 299 & \\
\hline \multicolumn{3}{|l|}{ Skipping meals } \\
\hline Yes & 224 & 74.9 \\
\hline No & 75 & 25.1 \\
\hline Total & 299 & \\
\hline \multicolumn{3}{|l|}{ Meal skipped } \\
\hline Breakfast & 112 & 47.3 \\
\hline Lunch & 116 & 48.9 \\
\hline Dinner & 9 & 3.8 \\
\hline Total & 237 & \\
\hline \multicolumn{3}{|c|}{ Consumption of Breakfast per week } \\
\hline $0-2$ & 42 & 14.5 \\
\hline $3-4$ & 75 & 25.9 \\
\hline $5-7$ & 172 & 59.5 \\
\hline Total & 289 & \\
\hline \multicolumn{3}{|l|}{ Lifestyle } \\
\hline \multicolumn{3}{|c|}{ Alcohol consumption } \\
\hline Yes & 72 & 24.1 \\
\hline No & 227 & 75.9 \\
\hline Total & 299 & \\
\hline \multicolumn{3}{|l|}{ Smoking } \\
\hline Yes & 10 & 3.3 \\
\hline No & 289 & 96.7 \\
\hline Total & 299 & \\
\hline \multicolumn{3}{|c|}{ Carbonated drinks consumption } \\
\hline Yes & 285 & 96.0 \\
\hline No & 12 & 4.0 \\
\hline Total & 297 & \\
\hline \multicolumn{3}{|c|}{ Days of exercise per week } \\
\hline None & 111 & 37.1 \\
\hline 1 day & 57 & 19.1 \\
\hline $2-3$ days & 86 & 28.8 \\
\hline $4-5$ days & 22 & 7.4 \\
\hline More than 5 days & 23 & 7.7 \\
\hline Total & 299 & \\
\hline \multicolumn{3}{|c|}{ Days of physical exercise in the past one week } \\
\hline None & 127 & 42.5 \\
\hline 1day & 55 & 18.4 \\
\hline $2-3$ days & 79 & 26.4 \\
\hline $4-5$ days & 15 & 5.0 \\
\hline More than 5 days & 23 & 7.7 \\
\hline Total & 299 & \\
\hline
\end{tabular}




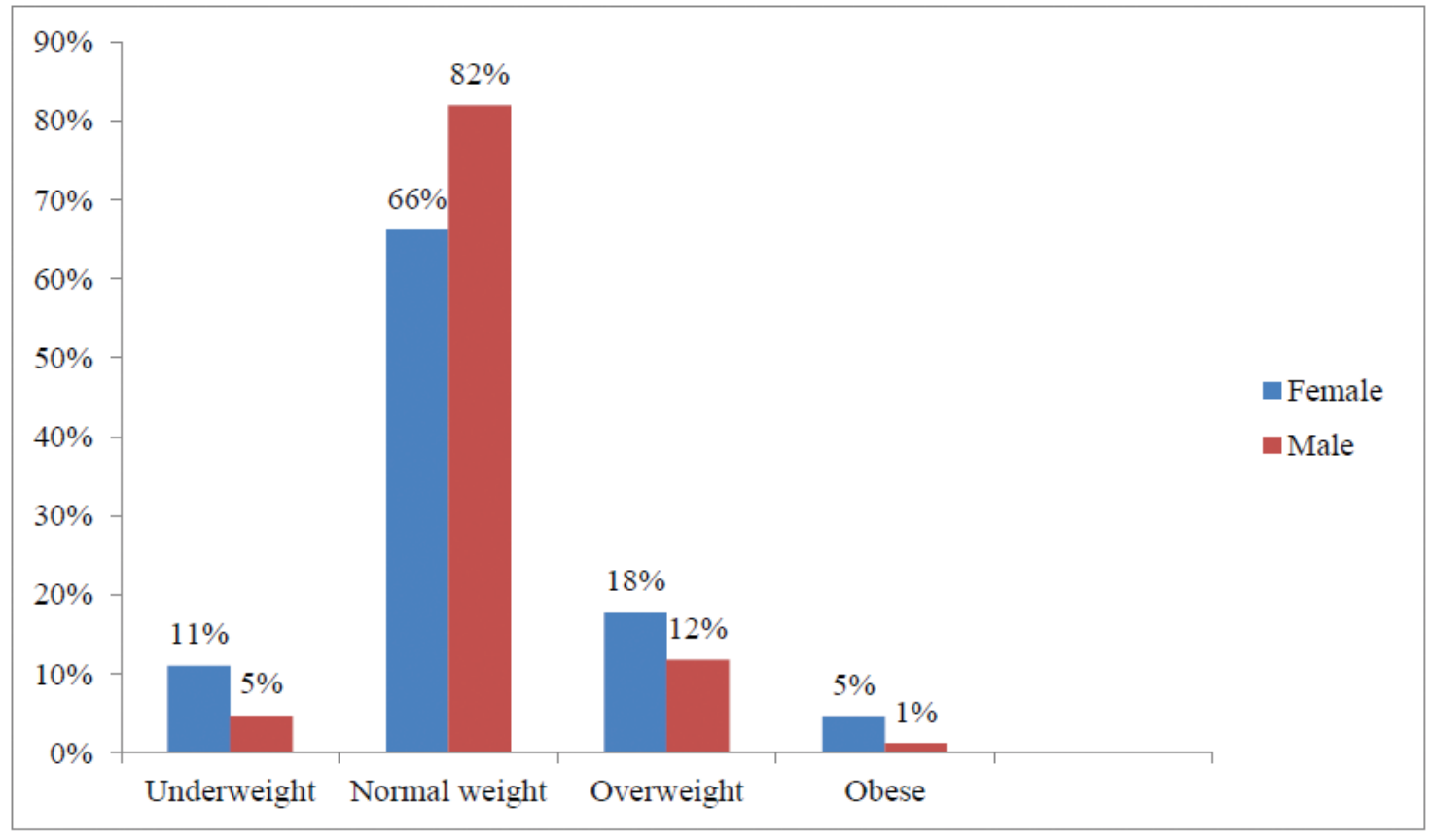

\section{$\mathrm{p}=\mathbf{0 . 0 5 5}$}

Figure 1: BMI distribution of respondents

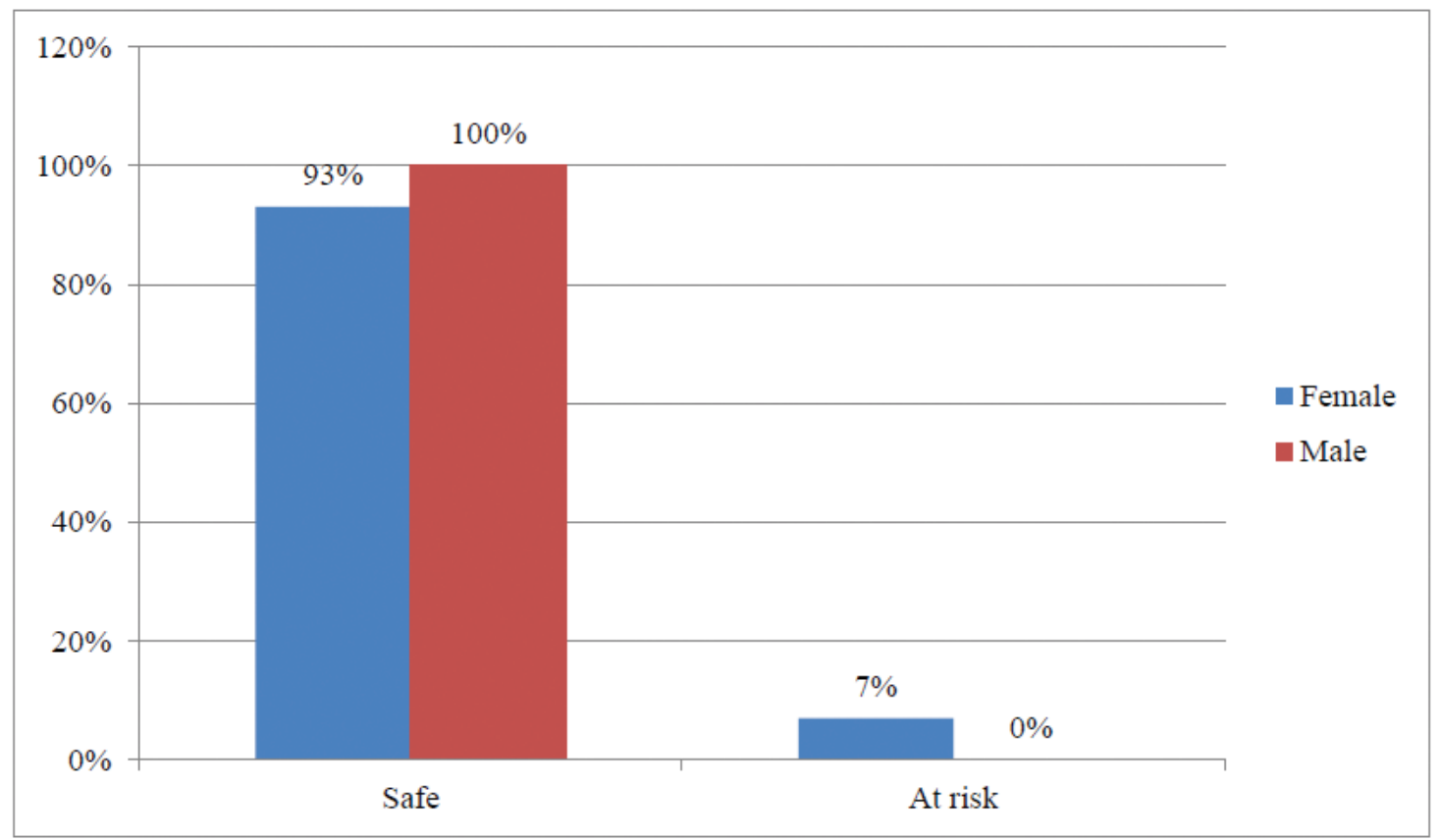

\section{$\mathrm{P}=\mathbf{0 . 0 0 0}$}

Figure 2: Waist circumference of respondents 


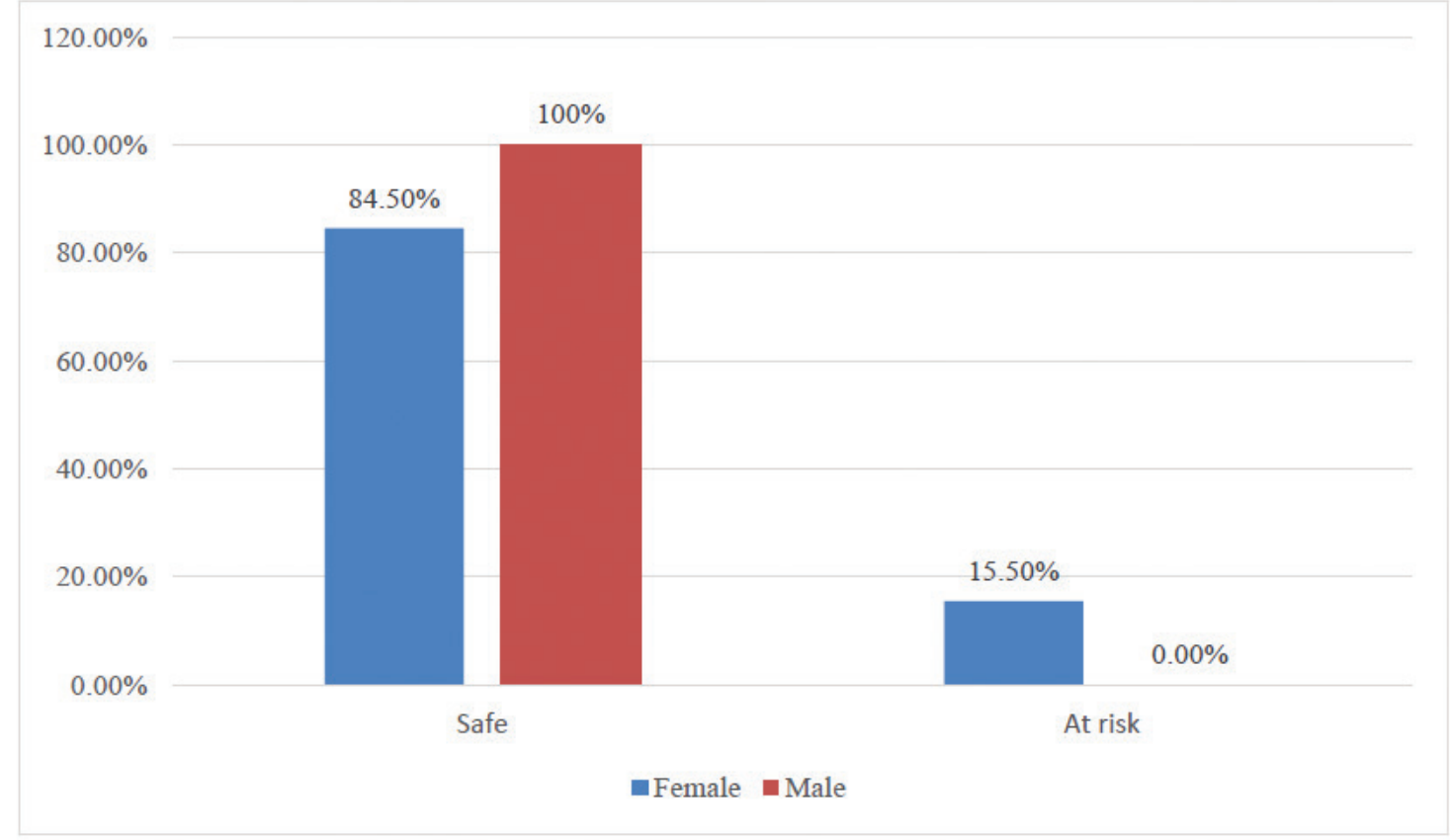

$\mathrm{P}=\mathbf{0 . 0 0 0}$

Figure 3: Waist-Hip-Ratio of respondents

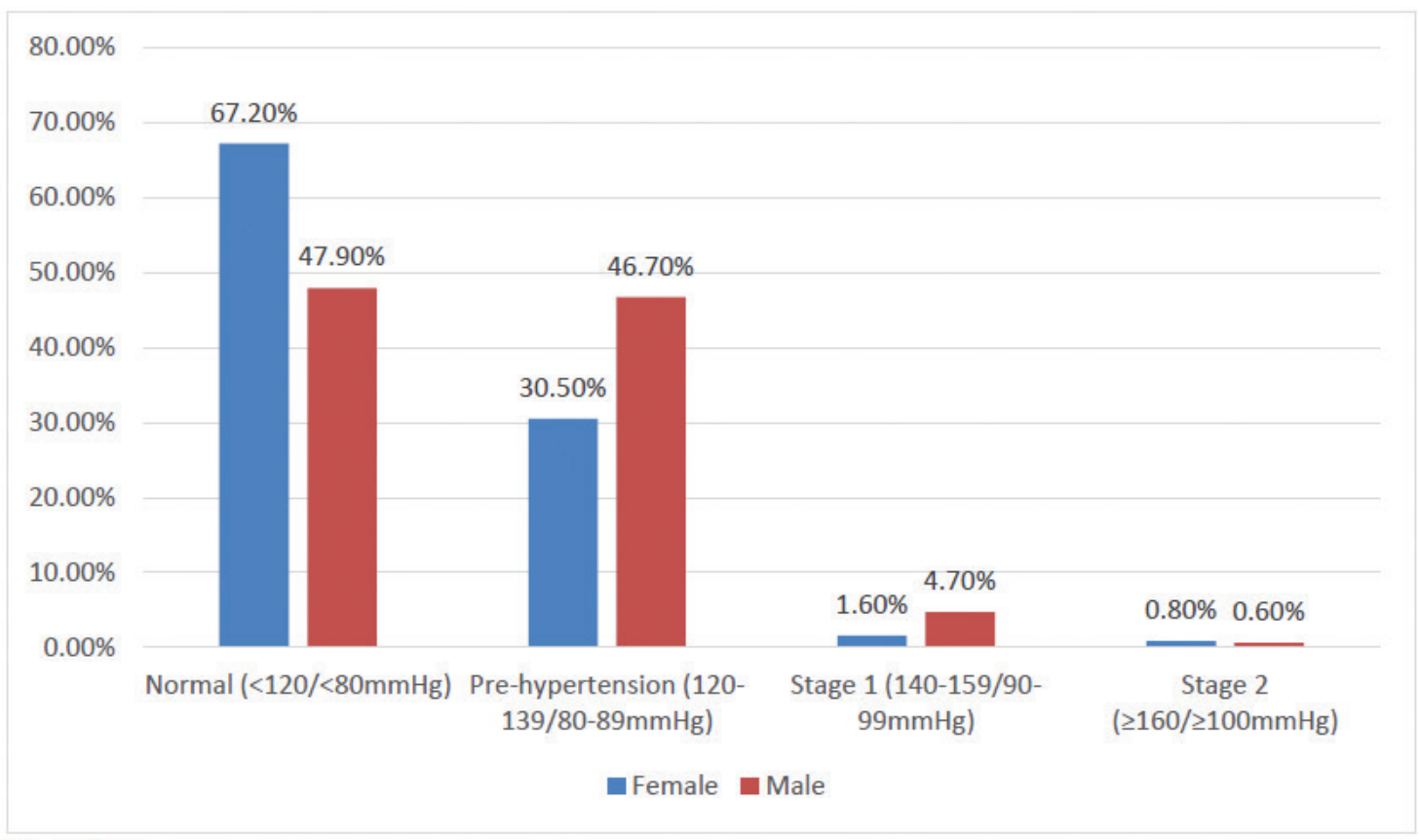

$\mathrm{P}=\mathbf{0 . 0 0 1}$

Figure 4: Blood pressure of respondents 
Table 3: BMI according to personal characteristics

\begin{tabular}{|l|l|l|l|l|l|}
\hline Characteristics & $\langle\mathbf{2 5} \mathbf{n}(\mathbf{\%})$ & $\mathbf{2 2 5} \mathbf{n}(\mathbf{\%})$ & Total n (\%) & $\mathbf{X}^{\mathbf{2}}$ & p-value \\
\hline Age & & & & & \\
\hline $15-20$ & $91(38.2)$ & $16(32.7)$ & $107(37.3)$ & 0.542 & 0.100 \\
\hline 21 and above & $147(61.8)$ & $33(67.3)$ & $180(62.7)$ & & \\
\hline Gender & & & & & \\
\hline Female & $101(40.7)$ & $29(56.9)$ & $130(43.5)$ & 4.482 & 0.013 \\
\hline Male & $147(59.3)$ & $22(43.1)$ & $169(56.5)$ & & \\
\hline Level & & & & & \\
\hline OND 1 & $124(50.2)$ & $23(45.1)$ & $147(49.3)$ & 1.092 & 0.041 \\
\hline OND 2 & $20(8.1)$ & $6(11.8)$ & $26(8.7)$ & & \\
\hline HND 1 & $33(13.4)$ & $6(11.8)$ & $39(13.1)$ & & \\
\hline HND 2 & $70(28.3)$ & $16(31.4)$ & $86(28.9)$ & & \\
\hline Monthly allowance ( $)$ & & & & & \\
\hline Less than 20,000 & $98(43.6)$ & $17(39.5)$ & $115(42.9)$ & 2.277 & 0.049 \\
\hline 20,000-29,000 & $45(20.0)$ & $13(30.2)$ & $58(21.6)$ & & \\
\hline $30,000-39,000$ & $13(5.8)$ & $2(4.7)$ & $15(5.6)$ & & \\
\hline Above 40,000 & $69(30.7)$ & $11(25.6)$ & & & \\
\hline
\end{tabular}

$\mathrm{P}<0.05$

of abdominal obesity. The waist-to-hip ratio (Table 4) reveals that students $\leq 20$ years $(63.2 \%)$ were at risk of central obesity and it was higher in females (100.0\%) than males $(0.0 \%)$ and in students that were receiving monthly allowance $<\$ 30,000.00$ (64.7\%).

\section{Blood Pressure According to Personal Characteristics}

Table 5 shows systolic and diastolic blood pressure according to personal characteristics. For systolic blood pressure, students aged $\geq 20$ years were at pre-hypertensive stage $(67.4 \%)$ and stage I hypertension $(77.8 \%)$. More males were at pre-hypertensive stage $(71.7 \%)$ and stage I hypertension (88.9\%). Overall, more respondents with monthly allowance $<\$ 30,000.00$ were at pre-hypertensive stage $(65.5 \%)$ and stage I hypertension $(71.5 \%)$. For diastolic blood pressure, more students $\geq 20$ years were at diastolic pre-hypertensive stage $(72.1 \%)$ and stage I hypertension $(100.0 \%)$. More males were at pre-hypertensive stage (56.5\%) and stage I hypertension (57.1\%). Overall, more respondents with monthly allowance $<\$ 30,000.00$ were at pre-hypertensive stage $(76.2 \%)$ and stage I hypertension $(71.5 \%)$. In addition, greater proportion of overweight/ obese students compare to normal weight students were in pre-hypertension (56.9\% versus $36.2 \%)$ and stage I hypertension ( $5.9 \%$ versus $2.8 \%$ ).

\section{Discussion}

In this study, the prevalence of overweight and obesity was assessed using BMI, waist circumference and waist-hipratio as parameters; its association with certain personal characteristics was investigated. Feeding habits and blood pressure were also assessed. The study reveals the occurrence of overweight and obesity among the study population.

\section{Feeding Habits}

The study shows that many of the students had inadequate feeding habits. More than one third of them consumed less than three meals in a day, although this result was higher than the finding of Ukegbu et al. (2017) which was $34 \%$ and lower than $60.7 \%$ of undergraduate students in Cameroun (Niba et al., 2017) and 83\% Lagos State University students in Southwest, Nigeria (Arisa et al., 2020). A large proportion of the students skipped meals and breakfast was the frequently skipped meal with about half of them. This was lower than the finding of Adesola et al. (2014) with 
Table 4: Waist circumference and waist-hip-ratio according to personal characteristics

\begin{tabular}{|c|c|c|c|c|c|}
\hline Characteristics & Safe n (\%) & At risk n (\%) & Total n (\%) & $\mathbf{X}^{2}$ & p-value \\
\hline \multicolumn{6}{|l|}{ Waist circumference } \\
\hline \multicolumn{6}{|l|}{ Age } \\
\hline $15-20$ & $103(37.1)$ & $4(50.0)$ & $107(34.4)$ & 0.557 & 0.212 \\
\hline 21 and above & $175(62.9)$ & $4(50.0)$ & $179(62.6)$ & & \\
\hline \multicolumn{6}{|l|}{ Gender } \\
\hline Female & $120(41.5)$ & $9(100.0)$ & $129(43.3)$ & 12.158 & 0.000 \\
\hline Male & $169(58.5)$ & $0(0.0)$ & $169(56.7)$ & & \\
\hline \multicolumn{6}{|l|}{ Level } \\
\hline OND 1 & $142(49.3)$ & $5(55.6)$ & $147(49.5)$ & 2.912 & 0.098 \\
\hline OND 2 & $26(9.0)$ & $0(0.0)$ & $26(8.8)$ & & \\
\hline HND 1 & $39(13.5)$ & $0(0.0)$ & $39(13.1)$ & & \\
\hline HND 2 & $81(28.1)$ & $4(44.4)$ & $85(28.6)$ & & \\
\hline \multicolumn{6}{|c|}{ Monthly allowance (N) } \\
\hline$<20,000$ & $110(42.6)$ & $5(55.6)$ & $115(43.1)$ & 1.032 & 0.081 \\
\hline $20,000-29,000$ & $56(21.7)$ & $2(22.2)$ & $58(21.7)$ & & \\
\hline $30,000-39,000$ & $15(5.8)$ & $0(0.0)$ & $15(5.6)$ & & \\
\hline Above 40,000 & $77(29.8)$ & $2(22.2)$ & $79(29.6)$ & & \\
\hline \multicolumn{6}{|l|}{ Waist-hip-ratio } \\
\hline \multicolumn{6}{|l|}{ Age } \\
\hline $15-20$ years & $95(35.6)$ & $12(63.2)$ & $107(37.4)$ & 5.761 & 0.012 \\
\hline 21 years and above & $172(64.4)$ & $7(36.8)$ & $179(62.6)$ & & \\
\hline \multicolumn{6}{|l|}{ Gender } \\
\hline Female & $109(39.2)$ & $20(100.0)$ & $129(43.3)$ & 28.087 & 0.000 \\
\hline Male & $169(60.8)$ & $0(0.0)$ & $169(56.7)$ & & \\
\hline \multicolumn{6}{|l|}{ Level } \\
\hline OND 1 & $135(48.7)$ & $12(60.0)$ & $147(49.5)$ & 1.694 & 0.048 \\
\hline OND 2 & $24(8.7)$ & $2(10.0)$ & $26(8.8)$ & & \\
\hline HND 1 & $38(13.7)$ & $1(5.0)$ & $39(13.1)$ & & \\
\hline HND 2 & $80(28.9)$ & $5(25.0)$ & 85 (28.6) & & \\
\hline \multicolumn{6}{|c|}{ Monthly allowance (N) } \\
\hline$<20,000$ & $107(42.8)$ & $8(47.1)$ & $115(43.1)$ & 1.426 & 0.077 \\
\hline $20,000-29,000$ & $55(22.0)$ & $3(17.6)$ & $58(21.7)$ & & \\
\hline $30,000-39,000$ & $15(6.0)$ & $0(0.0)$ & $15(5.6)$ & & \\
\hline Above 40,000 & $73(29.2)$ & $6(35.3)$ & $79(29.6)$ & & \\
\hline
\end{tabular}

$\mathrm{P}<0.05$

52\% of undergraduates in Ekiti State and 57\% in Malaysian university students (Kutty et al., 2015) and higher compared to the previous results in Nigeria which were between 33\% (Nmor et al., 2014) and 41.5\% (Ukegbu et al., 2015) and other countries which ranged between $23 \%$ and $42 \%$
(Gan et al., 2011; Bernardo et al., 2017; Niba et al., 2017). Breakfast is the most important meal of the day and it has been associated with overweight and obesity (Niba et al., 2017; Arisa et al., 2020). Regular skipping of breakfast may open door for excessive consumption of calories in terms 
Table 5: Blood pressure according to socio-demographic characteristics

\begin{tabular}{|c|c|c|c|c|c|c|}
\hline Variables & $\begin{array}{l}\text { Normal } \\
<120\end{array}$ & $\begin{array}{l}\text { pre-hypertension } \\
120-139\end{array}$ & $\begin{array}{l}\text { Stage } 1 \\
140-159\end{array}$ & $\begin{array}{l}\text { Stage } 2 \\
\geq 160\end{array}$ & $\mathbf{X}^{2}$ & p-value \\
\hline \multicolumn{7}{|l|}{$\begin{array}{l}\text { Systolic } \\
\text { Age }\end{array}$} \\
\hline $15-20$ & $74(40.9)$ & $31(32.6)$ & $2(22.2)$ & $0(0.0)$ & 3.344 & 0.017 \\
\hline 21 and above & $107(59.1)$ & $64(67.4)$ & $7(77.8)$ & $1(100)$ & & \\
\hline \multicolumn{7}{|l|}{ Gender } \\
\hline Female & $98(52.1)$ & $28(28.3)$ & $1(11.1)$ & $1(100)$ & 20.186 & 0.000 \\
\hline Male & $90(47.9)$ & $71(71.7)$ & $8(88.9)$ & $0(0.0)$ & & \\
\hline \multicolumn{7}{|l|}{ Level } \\
\hline OND 1 & 97 (51.9) & $47(47.5)$ & $1(11.1)$ & $1(100.0)$ & 13.903 & 0.007 \\
\hline OND 2 & $19(10.2)$ & $7(7.1)$ & $0(0.00)$ & $0(0.00)$ & & \\
\hline HND 1 & $19(10.2)$ & $18(18.2)$ & $2(22.2)$ & $0(0.00)$ & & \\
\hline HND & $252(27.8)$ & $27(27.3)$ & $6(66.7)$ & $0(0.00)$ & & \\
\hline \multicolumn{7}{|c|}{ Monthly allowance (N) } \\
\hline$<20,000$ & $75(44.4)$ & $37(41.1)$ & $3(42.9)$ & $0(0.00)$ & 6.568 & 0.034 \\
\hline $20,000-29,000$ & $33(19.5)$ & $22(24.4)$ & $2(28.6)$ & $1(100.0)$ & & \\
\hline $30,000-39,000$ & $12(7.1)$ & $3(3.3)$ & $0(0.0)$ & $0(0.0)$ & & \\
\hline Above 40,000 & $49(29.0)$ & $28(31.1)$ & $2(28.6)$ & $0(0.0)$ & & \\
\hline \multicolumn{7}{|l|}{$\begin{array}{l}\text { Diastolic } \\
\text { Age }\end{array}$} \\
\hline $15-20$ & $95(40.6)$ & $12(27.9)$ & $0(0.0)$ & $0(0.0)$ & & \\
\hline 21 and above & $139(59.4)$ & $31(72.1)$ & $7(100.0)$ & $1(100.0)$ & 7.443 & 0.002 \\
\hline \multicolumn{7}{|l|}{ Gender } \\
\hline Female & $104(43.0)$ & $20(43.5)$ & $3(42.9)$ & $0(0.0)$ & & \\
\hline Male & $138(57.0)$ & $26(56.5)$ & $4(57.1)$ & $1(100.0)$ & 0.758 & 0.093 \\
\hline \multicolumn{7}{|l|}{ Level } \\
\hline OND 1 & $122(50.6)$ & $22(47.8)$ & $1(14.3)$ & $0(0.0)$ & & \\
\hline OND 2 & $20(8.3)$ & $6(13.0)$ & $0(0.0)$ & $0(0.0)$ & & \\
\hline HND 1 & $33(13.7)$ & $4(8.7)$ & $2(28.6)$ & $0(0.0)$ & 10.111 & 0.007 \\
\hline HND 2 & $66(27.4)$ & $14(30.4)$ & $4(57.1)$ & $1(100.0)$ & & \\
\hline \multicolumn{7}{|c|}{ Monthly allowance (N) } \\
\hline$<20,000$ & $95(44.0)$ & $18(42.9)$ & $2(28.6)$ & $0(0.0)$ & & \\
\hline $20,000-29,000$ & $39(18.1)$ & $14(33.3)$ & $3(42.9)$ & $1(100.0)$ & & \\
\hline $30,000-39,000$ & $14(6.5)$ & $1(2.4)$ & $0(0.0)$ & $0(0.0)$ & 12.127 & 0.029 \\
\hline Above 40,000 & $68(31.5)$ & $9(21.4)$ & $2(28.6)$ & $0(0.0)$ & & \\
\hline
\end{tabular}

$\mathrm{P}<0.05$ 
of snacking and over consumption of food which may lay the foundation of overweight and obesity (Okafor et al., 2018). The skipping of meals by these students might be due to economic reason whereby two third of them received monthly allowance below $\$ 30,000.00$

\section{Lifestyle}

Most of the students consumed carbonated drinks and this was higher than $69 \%$ recorded in Umudike (Ukegbu et al., 2015) and 67\% among private university students in Ogun State, Nigeria (Okondu et al., 2020). One fifth of the students consumed carbonated drinks on daily basis. This result was lower compared to $29 \%$ obtained among university students in Lagos, Nigeria (Olatona, 2018). Increasing intake of carbonated drinks along with other junk foods had been observed to lead to inadequate nutrient intake and increasing prevalence of overweight and obesity (Ukegbu et al., 2015; Mohammadbeigi et al., 2018; Bakar et al., 2020).

\section{Physical Activity}

More than one thirds of the students did not engaged in physical activity at all and this was comparable to the result on Egyptian students with 37\% (Moussa et al., 2016) but lower than $67 \%$ to $92 \%$ recorded for previous studies in Nigeria (Ayodele et al., 2009; Maduka et al., 2017) and $39 \%$ to $54 \%$ in America (Katuka et al., 2016; Deng et al., 2017). Not engaging in physical exercise and decrease in physical activity have been associated with high central obesity among university students in Ghana (Mogre et al., 2014) and general obesity in Mexico (Sofia et al., 2015) and in USA (Katuka et al., 2016) and Yemen (Alhaj \& Alqubaty, 2020). Overweight and obese students (73\%) have been found not to meet physical activity level in USA (Oh et al., 2016).

\section{Overweight and Obesity}

The prevalence of general overweight and obesity measured by BMI was below one fifth, this was in line with other studies in Nigeria (Ayodele et al., 2009; Olusanya \& Omotayo, 2011; Olufemi \& Abiodun, 2013; Nmor et al., 2014; Odili et al., 2014; Bagi et al., 2017; Ukegbu et al., 2017; Maduka et al., 2017) and other African countries (Kolawole et al., 2017; Deng et al., 2017) and Asia (Kutty et al., 2015; Ren et al., 2015; Irfan, 2018). It was lower than other Nigerian studies which ranged from $20 \%$ to $60 \%$ (Adesola et al., 2014; Oladoyinbo \& Ekerette, 2015; Agwu et al., 2017; The GBD 2015 Obesity Collaborators, 2017;
Sedodo et al., 2020; Kayode \& Alabi, 2020) and other countries in Africa (Moussa et al., 2016; Niba et al., 2017), Asia (Davar, 2015), America (Katuka et al., 2016; Deng et al., 2017) and Europe (Sofia et al., 2015). The findings of Alhaj \& Alqubaty (2020) among private university students in Yemen show a higher prevalence.

Factors found to be associated with general overweight and obesity include gender, age and monthly allowance. It was higher in females than males. This finding was similar to the previous studies on Nigerian university students (Ayodele et al., 2009; Aliyu et al., 2014; Odili et al., 2014; Oladoyinbo \& Ekerette, 2015; Attah et al., 2016; Ukegbu et al., 2017; Eze \& Kadiri, 2020), Africa (Mogre et al., 2014a; Mogre et al., 2014b; Moussa et al., 2016, Niba et al., 2017) and other continent (Davar, 2015). It was contrary to the findings of some other studies in Nigeria (Nwachukwu et al., 2010; Olusanya \& Omotayo, 2011; Nmor et al., 2014; Ukegbu et al., 2017), Asia (Gan et al., 2011; Hujova, 2013; Kutty et al., 2015; Ren et al., 2015; Irfan, 2018), America (Moretti et al., 2014; Obesidade \& Obesidad, 2017; Deng et al., 2017) and Europe (Sofia et al., 2015) where general obesity was higher in males than females. It was also in contrast to the findings of Alhaj \& Alqubaty (2020) in Yemen. It was higher in older students (above 20 years) than adolescents (Issa, 2015). It was higher among students that received monthly allowance less than $\$ 30,000$.00. This was in contrast to Moretti et al. (2014); Kolawole et al. (2017); Obesidade \& Obesidad (2017) where students with higher monthly allowance were more obese compare to those with lower monthly allowance.

There was low risk of abdominal obesity measured by waist circumference. This finding was lower than Ukegbu et al. (2017) with $15 \%$. More females and students that received less than $\$ 30,000.00$ monthly allowance were at risk. This was in agreement with previous studies in Nigeria (Ayodele et al., 2009; Odili et al., 2014; Oladoyinbo \& Ekerette, 2015; Attah et al., 2016; Ukegbu et al., 2017) and contrary to Davar (2015).

Less than one tenth of the students were at risk of central obesity which was measured by waist-hip-ratio. This result was lower than Ukegbu et al. (2017) and Gyamfi et al. (2018). Risk of central obesity was higher in students less than 20years, females and those that received monthly allowance less than $\$ 30,000.00$. This outcome validated the findings of Odili et al. (2014), Attah et al. (2016) and Ukegbu et al. (2017), and ran contrary to that of Gan et al. (2011) where more males were at risk. Females have the tendency to accumulate fat than males and in Africa, being fatty is associated with beauty and affluence (Ukegbu et al., 2017). The high level of overweight/ obesity among these students was probably due to feeding pattern with skipping of meals and consumption of carbonated drinks coupled 
with low level of physical activity. Physical inactivity was found to contribute to obesity in $86 \%$ of university students in Southwest Nigeria (Okondu et al., 2020). In addition, students that received low monthly income might settle for less expensive foods which are majorly calorie dense foods leading to excessive weight gain. If overweight and obesity prevalence is not checked among this population group, it can be a risk factor for the development of noncommunicable diseases later in life.

\section{Blood Pressure}

One third of the students were at systolic pre-hypertension stage and this was higher than the result of Olatona et al. (2018) of $8 \%$. Less than $5 \%$ of the students were at stage I hypertension and the finding was similar to that of Olatona et al. (2018). Less than one fifth of the students were in pre-hypertension which was higher than the outcome of Olatona et al. (2018) in Nigeria. Less than 5\% were in stage I hypertension which was similar to $2.8 \%$ obtained by Olatona et al. (2018) and lower than 5.3\% of Okafor et al. (2018) on Nigerian students. Both systolic and diastolic prehypertension and stage I hypertension were higher in males than females, this result was similar to the results of previous studies (Ukegbu et al., 2017; Maduka et al., 2017; Alhawari et al., 2018; Agwo \& Adewumi, 2020; Gwarzo et al., 2020; Eze \& Kadiri, 2020). Elevated BP was more prevalence among students that received low monthly allowance and those that were overweight/obese. These findings were in agreement with those of Aliyu et al. (2014), Maduka et al. (2017); Ukegbu et al. (2017) in Nigeria and other countries (Gyamfi et al., 2018). Hence, there is need to put in place measures that will prevent excessive weight gain among these students.

\section{Conclusion and Recommendation}

The prevalence of overweight and obesity was evident among the study participants. There was high incidence of skipping breakfast, consumption of carbonated drinks, less engagement in physical activity and higher BP among overweight/obese students. Health promotion education with emphasis on adequate feeding habits and involving in physical activity is therefore recommended for the students of higher institution in the study area.

\section{Acknowledgements}

We acknowledge and appreciate all the students that participated in the study and the Authority of the institution for given the permission to carry out the study.

\section{References}

Abdulfatah, H.A. (2020). Unhealthy dietary as a lifestylerisk determinant of non-communicable diseases among Federal University students in North-West Zone, Nigeria. KIU Journal of Humanities, 5(3), 163171.

Olufemi, A.J., \& Abiodun, L.L. (2013). Prevalence of overweight and obesity in an institutionalized multi ethnic based male adult sample. International Journal of Humanities and Social Science, 3(5), 234-237.

Adesola, O.A., Ayodeji, R.-A.M., Akorede, Q.J., \& Oluranti, O., (2014). Breakfast habit and nutritional status of undergraduates in Ekiti State, Nigeria. Science Journal of Public Health, 2(4), 252-256. https://doi. org/10.11648/j.sjph.20140204.11

Agwo, E.O., Adewunmi, H.O. (2020). Effect of alcohol consumption on the nutritional status of male diploma students in the Federal Polytechnic, Ilaro. Journal of Women in Technical Education and Employment (JOWITED), The Federal Polytechnic, Ilaro Chapter, 1(1), 62-68.

Agwu, E.M., Draper, S., Croix, M.D.S., Egimot-Nwadiaro, R., \& Onuoha, C.R. (2017). Health rating, obesity and hypertension among university students in Nigeria by gender and ethnicity. World Journal of Public Health, 2(4), 131-143.

Alaba, K.E. (2018). The influence of nutrition education on dietary pattern and eating habits among female students of The Federal Polytechnic, Ilaro. Nigerian Journal of Tropical Agriculture, 18, 145-154.

Alhaj, A., \& Alqubaty, A.R. (2020). Prevalence and risk factors associated with obesity among students of a private university in Sana'a, Yemen. International Journal of BioMedicine and Public Health, 3(2), 30-34.

Alhawari, H.H., Al-Shelleh, S., Alhawari, H.H., AlSaudi, A., Al-Majali, D.A., Al-Faris, L., \& AlRyalat, S.A. (2018). Blood pressure and its association with gender, body mass index, smoking, and family history among university students. International Journal of Hypertension, 2014, 4186496. https://doi. org/10.1155/2018/4186496

Aliyu, S.U., Ahmad, J.T., \& Oyeyemi, A.Y. (2014). Relationship between body mass index and blood pressure among university students in Maiduguri, Nigeria. International Journal of Recent Advances in Multidisciplinary Research, 1(11), 091-096.

Arisa, N., Anaemene, D., \& Mekwunye, W. (2020). Assessment of overweight, obesity and the dietary habits of undergraduate students of Lagos State 
University. European Journal of Nutrition and Food Safety, 12(5), 25-34. https://doi.org/10.9734/ ejnfs/2020/v12i530225

Attah, M.O.O., Chiroma, M.S, Ishaya, H.B., Paul, A., \& Jacob, A. (2016). Measurement of obesity as indicated by body mass index using waist-hip ratio among apparently healthy students in University of Maiduguri, Nigeria. Nova Journal of Medical and Biological Sciences, 5(3), 1-5. https://doi.org/10.20286/jmbs-050305

Ayodele, O.E., Akanbi, O.O., Akinwusi, P.O., Hassan, A.O., \& Ogunro, P.O. (2009). Urinary abnormalities, blood pressure and anthropometric profiles among students in a Nigerian University. Tropical Journal of Nephrology, 4(1), 21-29.

Bagi, S.J., Daniel, E.E., Rabiu, K.M., \& Ezekiel, I. (2017). Assessment of body weight, body mass index and waist-hip ratio on academic performance of female students in Akanu Ibiam Federal Polytechnic Unwana, Afikpo, Ebonyi State, Nigeria. International Journal of Brain and Cognitive Sciences, 6(4), 65-70.

Bakar, A.A.A., Hussin, N., Jalil, A.M.M., \& Mohamad, M. (2020). Association between sugar-sweetened beverage consumption and body mass index among university students in Kuala Nerus, Terengganu, Malaysia. Malaysian Journal of Public Health Medicine, 20(2), 19-26. https://doi.org/10.37268/mjphm/vol.20/no.2/ art.323

Bernardo, G.L., Jomori, M.M., Fernandes, A.C., \& Proenç, R.P.C. (2017). Food intake of university students. Revista de Nutricao, 30(6), 847-865. https://doi. org/10.1590/1678-98652017000600016

Davar, V. (2015). Body composition analysis of university students by anthropometry and bioelectrical impedance analysis. International Journal of Medical and Health Sciences, 9(6), 492-496.

Deng, X., Castelli, D., Castro-Pinero, J., \& Guan, H. (2017). University students meeting the recommended standards of physical activity and body mass index. Journal of Research, 6(1), 20-26.

Ezeh, E.C., \& Kadiri, S. (2020). Blood pressure, hypertension and obesity in young adults in a tertiary health institution in Southwest Nigeria. African Journal of Biomedical Research, 23(SE1), 81-84.

Gan, W.Y., Mohd, N.M.T., Zalilah, M.S., \& Hazizi, A.S. (2011). Differences in eating behaviours, dietary intake and body weight status between male and female Malaysian University students. Malaysian Journal of Nutrition, 17(2), 213-228

Gwarzo, I.M., Adam, M.N., Wali, N.Y., \& Ibrahim, S.A. (2020). Correlation of anthropometric indices with fasting blood glucose and blood pressure among university students in Kano, Nigeria. Nigerian Journal of Basic and Clinical Sciences, 17(2), 128-134. https:// doi.org/10.4103/njbcs.njbcs_38_19

Gyamfi, D., Obirikorang, C., Acheampong, E., Danquah, K.O., Asamoah, E.A., Liman, F.Z., Batu, E. N. (2018). Prevalence of pre-hypertension and hypertension and its related risk factors among undergraduate students in a tertiary institution, Ghana. Alexandria Journal of Medicine, 54(4), 475-480. https://doi.org/10.1016/j. ajme.2018.02.002

Hujová, Z. (2013). The prevalence of obesity and hypertension among first-year students at Trnava University in Slovakia. International Journal of Medicine and Medical Sciences, 5(8), 361-367.

Ikujenlola, A.V., \& Adekoya, T.S. (2020). Nutritional status and feeding habits of females in public and private universities in Osun State, Southwestern, Nigeria. Heliyon, 6(9), e05023. https://doi.org/10.1016/j. heliyon.2020.e05023

Irfan, M. (2018). Nutritional habits and obesity: A case study among Pakistani Universities Students. Journal of Food and Nutritional Disorders, 7(2). https://doi. org/10.4172/2324-9323.1000249

Issa, L.F. (2015). Prevalence and risk factors of obesity and overweight among Taif University students, Taif, Saudi Arabia. International Journal of Public Health and Epidemiology, 4(1), 98-106

Katuka, S.K., Faleti, O.C., Medavarapu, S., Ogungbite, A., Ugokwe, C.J., Umoffia, I.R., \& Sangem, A. (2016). The prevalence of underweight, overweight, obesity and the influence of exercise and diet on body weight among medical students. Archives of Medicine, 8(5), https://doi.org/10.21767/1989-5216.1000164

Kayode, O.O., \& Alabi, Q.K. (2020). Food consumption patterns, physical activity and overweight and obesity among undergraduates of a private university in Nigeria. Clinical Nutrition Experimental, 31, 28-34. https://doi.org/10.1016/j.yclnex.2020.01.001

Kolawole, A.K., Kevin, N.U., Oluwole, I., \& Ademola, S. (2017). The association of socio-demographic factors with overweight/obesity among students (Ages 18-35 years) in Cavendish University. Uganda. Epidemiology (Sunnyvale), 7(6), 1000328. https://doi. org/10.4172/2161-1165.1000328

Kutty, N.A.M., Ru, T.Y., Chiang, V.H.Q., \& Zhi, W.Y. (2015). Association of dietary habits and body mass index among university students in Malaysia: A crosssectional study. IOSR Journal of Nursing and Health Science, 4(5), 78-85. 
Maduka, O., Ezema, U.G., \& Ofori, S. (2017). Elevated blood pressure and cardiovascular risk factors among a cohort of young adults: findings from a tertiary institution in South-South Nigeria. The Nigerian Health Journal, 17(3), 79-89.

Mansouri, M., Hasani-Ranjbar, S., Yaghubi, H., Rahmani, J., Tabrizi, Y.M., Keshtkar, A., Varmaghani, M., Sharifi, F., \& Sadeghi, O. (2018). Breakfast consumption pattern and its association with overweight and obesity among university students: a population-based study. Eating and Weight Disorders - Studies on Anorexia, Bulimia and Obesity, 25, 379-387. https://doi. org/10.1007/s40519-018-0609-8

Mogre, V., Aleyira, S., \& Nyaba, R. (2014). Factors associated with central overweight and obesity in students attending the University for Development Studies in Tamale, Ghana: a cross-sectional study. South African Journal of Clinical Nutrition, 27(2), 69-74. https://doi. org/10.1080/16070658.2014.11734490

Mogre, V., Nyaba, R., \& Aleyira, S. (2014). Lifestyle risk factors of general and abdominal obesity in students of the school of medicine and health science of the University of Development Studies, Tamale, Ghana. International Scholarly Research Notices, 2014, 508382. https://doi.org/10.1155/2014/508382

Mohammadbeigi, A., Asgarian, A., Moshir, E., Heidari, H., Afrashteh, S., Khazaei, S., \& Ansari, H. (2018). Fast food consumption and overweight/obesity prevalence in students and its association with general and abdominal obesity. Journal of Preventive Medicine and Hygiene, 59(3), E236-E240. https://doi. org/10.15167/2421-4248/jpmh2018.59.3.830

Moretti, G. de S., Muniz, P.T., Tavares, C.M., Brunken, G.S., de Farias Júnior, J.C., \& Farias, E. dos S. (2014). Prevalence of and factors associated with overweight among university students from Rio Branco, Acre - Brazil. Revista Brasileira Cineantropometria e Desempenho Humano, 16(4), 406-418. https://doi. org/10.5007/1980-0037.2014v16n4p406

Moussa, M.M.M., El-mowafy, R.I., \& El-Ezaby, H.H. (2016). Prevalence of hypertension and associated risk factors among university students: Comparative study. Journal of Nursing Education and Practice, 6(5), 19-27. https://doi.org/10.5430/jnep.v6n5p19

Niba, L.L., Mary, B., Atanga, M.B., \& Navti, L.K. (2017). A cross sectional analysis of eating habits and weight status of university students in urban Cameroon. BMC Nutrition, 3, 55. https://doi.org/10.1186/s40795017-0178-7

Nmor, J., Nwaka, K.H., \& Nmor, J. C. (2014). Eating behaviours of university students in Southern Nigeria: an evaluation of sex differences. Science Journal of Public Health, 2(1), 23-37. https://doi.org/10.11648/j. sjph.20140201.14

Nwachukwu, D.C., Nwagha, U.I., Obikili, E.N., Ejezie, F.E., Okwuosa, C.N., Nweke, M.L., \& Ezeh, C.O. (2010). Assessment of body mass index and blood pressure among university students in, Enugu, South East, Nigeria. Nigerian Journal of Medicine, 19(2), 148-152. https://doi.org/10.4314/njm.v19i2.56503

Obesidade, S.E., \& Obesidad, S.Y. (2017). Overweight and obesity: Association with the socioeconomic level of university students. Journal of Nursing UFPE, 11(10), 3807-3812.

Odili, V.U., Egor, F.O., Osarenmwinda, I.M., \& Obieche, A.O. (2014). Prevalence of overweight and obesity among pharmacy students in a university in Benin City, Nigeria. Tropical Journal of Pharmaceutical Research, 13(12), 2109-2114. https://doi.org/10.4314/tjpr. v13i12.23

Oghagbon, K.E., Odili, V.U., Nwangwa, E.K., \& Pender, K.E. (2009). Body mass index and blood pressure pattern of students in Nigerian university. International Journal of Health Research, 2(2), 177-182. https://doi. org/10.4314/ijhr.v2i2.55416

Oh, Y., Kang, B.J., Yoo, S., \& Lopez, A. (2016). Overweight and obese college students' perceived barriers and motivators for a healthy lifestyle. European Journal of Educational Sciences, 3(4), 17-26. https://doi. org/10.19044/ejes.v3no4a17

Okafor, A.M., Nwazojie, I.Z., \& Afiaenyi, I.C. (2018). Nutrition knowledge and factors associated with anthropometric and haematological indices among female undergraduate students in University of Nigeria, Nsukka. Journal of Tropical Agriculture, Food, Environment and Extension, 17(2), 58-64. https://doi. org/10.4314/as.v17i2.8

Okondu, O.E., Ogueri, C., Afolabi, A., \& Ifediora, U. (2020). Dietary Practices Associated with Obesity among Babcock University Students in IlishanRemo, Ikenne Local Government Area, Ogun State, Nigeria. Preprints, 2020, 2020050228. https://doi. org/10.2094/preprints202005.0228.v1

Oladoyinbo, C.A., \& Ekerette, N.N. (2015). Double Burden of Malnutrition among Undergraduates in Ogun State Nigeria. International Journal of Public Health Science (IJPHS), 4(4), 315-319. https://doi. org/10.11591/ijphs.v4i4.4752

Olatona, F.A., Onabanjo, O.O., Ugbaja, R.N., Nnoaham, K.E., \& Adelekan, D.A. (2018). Dietary habits and metabolic risk factors for non-communicable diseases in a university undergraduate population. Journal of 
Health, Population and Nutrition, 37, 1-9. https://doi. org/10.1186/s41043-018-0152-2

Olumakaiye, M.F., Ogbimi, G.E, Ogunba, B.O., \& Soyebo, K.O. (2010). Snacking as a contributor to overweight among Nigerian undergraduate students. Nigerian Journal of Nutritional Sciences, 31(2), 76-80. https:// doi.org/10.4314/njns.v31i2.63921

Olusanya, J.O., \& Omotayo, O.A. (2011). Prevalence of Obesity among Undergraduate Students of Tai Solarin University of Education, Ijagun, Ijebu-Ode. Pakistan Journal of Nutrition, 10(10), 940-946. https://doi. org/10.3923/pjn.2011.940.946

Ren, X., Chen, Y., He, L., Jin, Y., Tian, L., Lu, M., Lu, W., Ding, L. Guo, D., Wang, L., Nie, Z., \& Yao, Y. (2015). Prevalence of underweight, overweight and obesity in university students from the region of Anhui (China). Nutricion hospitalaria, 31(3), 1089-1093. https://doi. org/10.3305/nh.2015.31.3.8395

Sedodo, N.S., Abosede, O.P., Ilori, O.A., Adenekan, M.K., Idowu, O.M., Nupo, A.O., \& Akinlotan, J.V. (2020). Assessment of fasting blood glucose level of undergraduates in Abeokuta Ogun State Nigeria. Archives of Current Research International, 20(5), 4249. https://doi.org/10.9734/acri/2020/v20i530196

Sofía, R.B.A., María, T.T.L., del Pilar, P.D.M., Dario, G.H., Adame, N.A.E., \& Guillermo, O.V. (2015). Prevalence and Factors Associated with Overweight and Obesity among University Students of the Health Field in San
Luis Potosí México. Health, 7(3), 328-335. https:// doi.org/10.4236/health.2015.73037

Tapera, R., Merapelo, M.T., Tumoyagae, T., Maswabi, T.M., Erick, P., Letsholo, B., \& Mbongwe, B. (2017). The prevalence and factors associated with overweight and obesity among University of Botswana students. Cogent Medicine, 4(1), 1357249. https://doi.org/10.1 080/2331205X.2017.1357249

The GBD 2015 Obesity Collaborators (2017). Health effects of overweight and obesity in 195 countries over 25 years. The New England Journal of Medicine, 377(1), 13-27. https://doi.org/10.1056/NEJMoa1614362

Ukegbu, P.O., Uwaegbute, A.C., Echendu, C.A., Ejike, C., Anyika-Elekeh, J.U, Asumugha, V.U., Kuyik, S.A., Omodamiro, S., Nwofia, B., Uzokwe, C., OluchiNliam, C., \& Uwakwe, N. (2017). Obesity and associated factors in young adults attending tertiary institutions in south-eastern Nigeria. South African Journal of Clinical Nutrition, 30(2), 43-48. https://doi. org/10.1080/16070658.2016.1259032

Ukegbu, P.O., Uwaegbute, A.C., \& Usonka, V.A. (2015). Contribution of snacks to energy and nutrient intake of undergraduates in a Nigerian university, Malaysian journal of nutrition, 21(1), 15-23.

WHO (2003). Promoting mental health. World Health Organizations report 2003; P27. Retrieved on February 10,2019, from https://www.who.int/mental_health/ evidence/en/promoting_mhh.pdf 


\section{药 \\ CHITKARA}

\section{Journal of Multidisciplinary Research in Healthcare}

Chitkara University, Saraswati Kendra, SCO 160-161, Sector 9-C, Chandigarh, 160009, India

Volume 7, Issue 1

October 2020

ISSN 2393-8536

Copyright: [@ 2020 I.O. Dada and I.A. Igbe] This is an Open Access article published in Journal of Multidisciplinary Research in Healthcare (J. Multidiscip. Res. Healthcare) by Chitkara University Publications. It is published with a Creative Commons Attribution- CC-BY 4.0 International License. This license permits unrestricted use, distribution, and reproduction in any medium, provided the original author and source are credited. 